\title{
Historein
}

Vol 14, No 1 (2014)

On the Edge of History and Philosophy

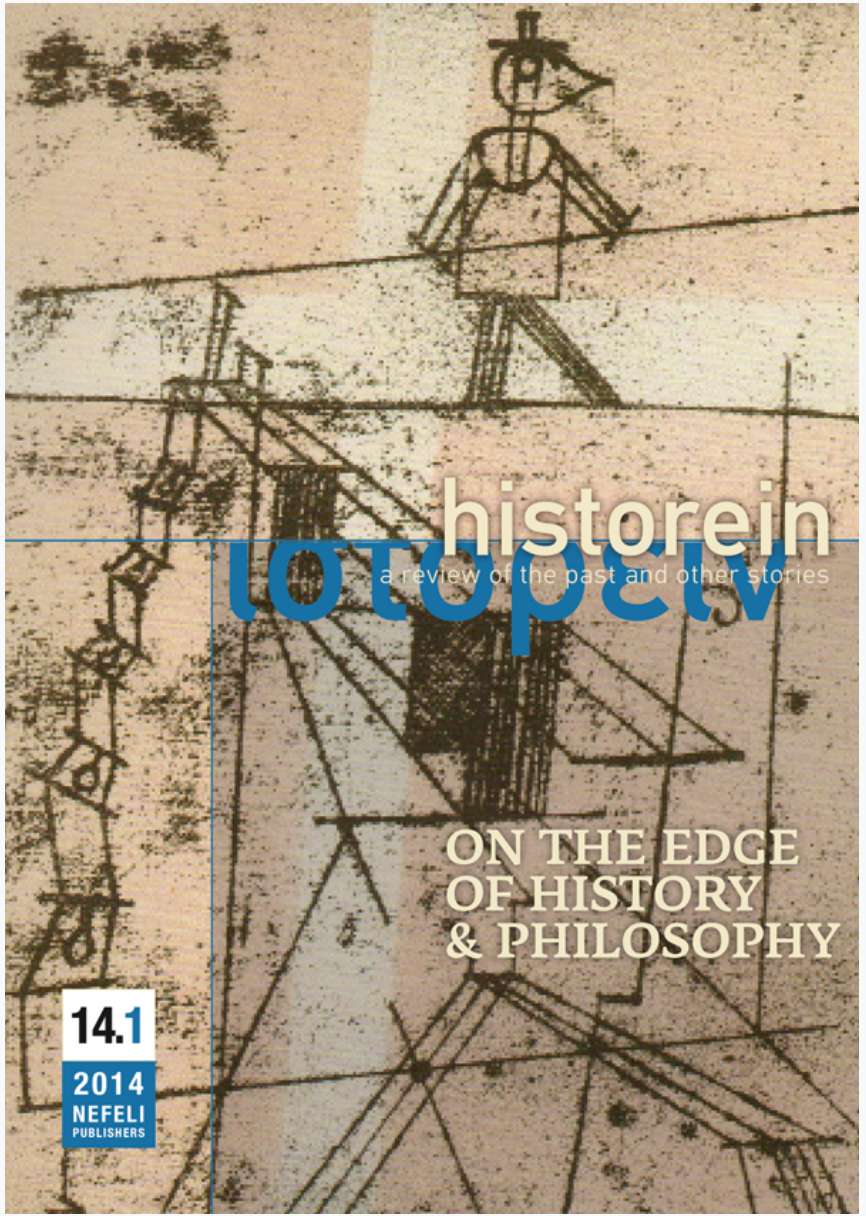

\section{Between positivism and narrativism in Polish methodology of history}

Krzysztof Brzechczyn

doi: $10.12681 /$ historein.234

Copyright @ 2014, Krzysztof Brzechczyn

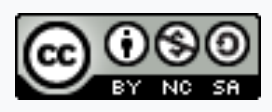

This work is licensed under a Creative Commons Attribution-NonCommercialShareAlike 4.0.

\section{To cite this article:}

Brzechczyn, K. (2013). Between positivism and narrativism in Polish methodology of history. Historein, 14(1), 75-87. https://doi.org/10.12681/historein.234 
This paper has two main purposes. Its primary purpose is to present the reception of the discussion between positivism and narrativism in Polish methodology of history. A secondary one is to paraphrase, using the notion apparatus of the idealisational theory of science, the issue of the accuracy of explanation. The paper consists of six parts. In the first, Hempel's deductivenomological (or covering law) model of explanation is presented. In the second part, the main tenets and assumptions of the Poznan school of methodology are described. The emergence of this school at the end of the 1960s was one of the most important intellectual phenomena in the cultural history of postwar Poland. However, the influence of the Poznan school postponed the popularisation of narrativism in the Polish methodology of history. The third part analyses the manifold reasons for this delayed reception. The popularisation of narrativism was only possible in Poland after 1989 but it had primarily an imitative character. This outline of the cultural and scientific context allows Chris Lorenz's proposals (on the problem of the accuracy of explanation) to be put in a wider perspective (part four). Namely, this author describes "a theoretical historical debate" on the status of scientific laws and talks about a postpositivistic approach to science represented by Nancy Cartwright. This approach was to introduce new perspectives to the understanding of lawfulness. In the fifth part of the article, the main assumptions and tenets (for example, the modes of explanation) of another post-positivistic approach to science, namely the idealisational theory of science, are presented and compared with the Hempelian model of explanation. In the final part, Hempel's explanatory sketch is paraphrased using the notion apparatus of the idealisational model of science which provides
Between positivism, narrativism and idealisation in Polish methodology of history

\section{Krzysztof Brzechczyn}

Adam Mickiewicz University, Poznań 
Between positivism, narrativism and idealisation in Polish methodology of history

a solution, within this theoretical framework, to the problem of the accuracy of explanation posed by Lorenz.

\section{I}

Proposed by Carl G. Hempel, the deductive-nomological (or covering-law) model of explanation initiated a discussion about the status and peculiarities of explanation in history. According to Hempel:

general laws have quite analogous functions in history and in natural sciences, that they form an indispensable instrument of historical research, and that they even constitute the common basis of various procedures which are often considered as characteristic of the social in contradistinction to the natural sciences ... In history no less in any other branch of empirical inquiry, scientific explanation can be achieved only by means of suitable general hypothesis, or by theories, which are bodies of systematically related hypotheses.

The deductive-nomological (or covering law) model of explanation consists of the explanandum, that is, the sentence that describes the phenomenon to be explained (the sentence, not the phenomenon as such), and of the explanans, which contains explanatory sentences. The explanans consists of a description of the antecedent conditions and of sentences containing general laws. The model of explanation can be presented in the following way: ${ }^{2}$

$C_{l}, C_{2}, \ldots, C_{n}$ - sentences stating antecedent conditions

$L_{1}, L_{2}, \ldots, L_{n}-$ sentences containing general laws

$E$ - sentence describing the phenomenon that is to be explained (explanandum)

The adequacy of this model of explanation depends on certain logical and empirical conditions. The explanandum must be logically deduced from the explanans. The explanans should contain a general law and description of the antecedent conditions. A scientific law should not contain proper names or temporal-spatial determinants. Both the sentences containing the general law, as well as those describing antecedent conditions, should be equipped with empirical content so that they can be tested by experiment or observation. ${ }^{3}$

In a discussion on Hempel's proposal that lasted more than half a century, three general positions can be distinguished: assimilationism, autonomism and methodological revisionism. ${ }^{4}$ The followers of assimilationism admitted that the deductive-nomological model, obligatory in the natural sciences, can be applied to explanation in historiography, although they saw the necessity of small corrections and modifications to reflect some of the peculiarities of historiographical research. The followers of autonomism claimed that this model did not reflect historiographical research procedures at all. Historiography, they argued, is about the understanding and interpretation of historical facts rather than their explanation, in the sense adopted by the natural sciences. A middle position was taken by methodological revisionists, who proclaimed the necessity of retaining Hempel's model but at the price of introducing a significant modification, so that the model would 
reflect the specificity of historiographical research. However, none of the discussants questioned the adequacy of a Hempelian model of explanation with regards to natural science. Rather, a discussion was held on whether and how to apply the deductive-nomological model in the domain of historical sciences (or more widely, that is, in the humanities).

\section{II}

However, the discussion in Poland on the status of the deductive-nomological model of explanation in history took on different forms than in the Anglo-American and western world. ${ }^{5}$ After the second world war, Poland was dependent on the Soviet Union and became a member of the Eastern bloc. During the Stalinist period (1948-1956), Marxism was imposed as an official ideology. The Poznań uprising of 28 June 1956 and civil protests that October brought about political reforms and certain level of cultural and political liberalisation. Isolation from the west was partially broken and Polish culture received more freedom to develop. After 1956, it was possible for different schools of Marxism, apart from the official dogmatic line, to emerge; other philosophical orientations also resurfaced.

One such interpretation of Marxism was elaborated by the Poznań school of methodology, which emerged in late 1960. This scientific milieu gathered around Jerzy Kmita (1931-2012), Leszek Nowak (1943-2009) and Jerzy Topolski (1928-1998) and drew intellectual inspirations from three sources: analytical philosophy developed in the Warsaw-Lwów (Lviv) school of prewar Poland, Popperian hypotheticism and Marxism (especially Marx' methodological ideas and some conception of historical and dialectical materialism). ${ }^{6}$ The combination of these three sources contributed to an original naturalistic but antipositivistic interpretation of Marxism and the establishment of a "full-blooded" research programme into the methodology of the humanities as well as the social and natural sciences. Its main features were naturalism, hypotheticism, essentialism, idealisation and rationalism. It was assumed that these same research methods should be employed in the sciences and humanities. Moreover, research practice and empirical observation are steered by hypotheses/theories or research problems that have been consciously put forward. Furthermore, it was supposed that the reality under investigation consists of both basic and secondary properties/factors and relationships. This differentiation justified a procedure of modelling, allowing the selection of basic dimensions of the investigated reality over the less important. In the humanities, the specific research procedure was a humanistic interpretation and assumption of rationality, which fulfils a similar role as that of law in a deductive-nomological model of explanation. ${ }^{7}$

The Poznan school elaborated an alternative to the Hempel-Popper proposal for a research model in the natural sciences and humanities. One of the most important achievements of this intellectual milieu was the idealisational theory of science. ${ }^{8}$ The main idea of this approach to science (more technical tenets of it will be presented in the fifth part, below) is the belief that a scientific theory is not a generalisation of facts or a deductive-hypothetical system but, rather, that it begins with a radical deformation of reality. In the first, most idealised, model of the theory, it is shown how the investigated phenomenon depends only on its principal factor. As a result, idealisational law has the form of a conditional statement. Its antecedent involves counterfactual assumptions, based on which factors recognised as secondary to a phenomenon under study are disregarded. 
The successor of idealisational law presents dependency between the studied phenomenon and its principal factor(s). The resulting idealisational statement is, therefore, valid under the accepted idealising assumptions. The theory resembles more a caricature than photography, in that a cartoonist omits certain features and magnifies other features which he or she deems characteristic. In this way, we can recognise the caricatured person. However, this analogy between theory and caricature should not be understood too literally. The cartoonist stops when s/he draws a caricature. A scientist, on the other hand, progressively corrects this simple picture of a phenomenon dependent only on the principal factor. He waives idealising assumptions, excluding the influence of some secondary factors, and shows how factors that were ignored in the initial model modified basic dependencies. In this way, a scientific theory is built which is a hierarchy of models, approaching more and more the complexity of the investigated phenomena.

Besides Kmita and Nowak, the third founder of the Poznań school was Topolski, who originally extended and applied their concepts in the domain of methodology of history. ${ }^{9}$ Topolski's most important achievement was the so-called "dynamic concept of the historical source", the concept of an integral explanation and theory of historical narrative. According to Topolski, a historical source is an informational structure constituted by set of questions posed by the historian. These research questions depend on the methodological and theoretical knowledge of the historian steering the whole process of searching for source information. Therefore, one cannot talk about a fixed reliability of a historical source because its value depends on the questions posed by researchers. Topolski distinguished between what-questions and why-questions. The answer to the first kind of question leads to a reconstruction of past reality. The answer to the second kind leads to its explanation. The Polish methodologist also presented an original concept of integral explanation that could grasp both the motivational structure of individuals and social (class) structures. The action of individuals is explained by an assumption of their rationality, whereas the deductive-nomological model is employed in an explanation of the dynamics of social structures. ${ }^{10}$

The results of a historian's research are presented in the form of a narrative which is a certain whole (he coined the term "historiographical picture"), consisting of idiographical as well as theoretical layers. The truth of the narrative depends on the theoretical layer, which contains laws, basic relationships and dependencies. Therefore, according to Topolski, "a proportionately greater share in a narrative (story) of true statements as compared with another narrative (story) does not guarantee a greater degree of truth of the former".11

\section{III}

The Poznań school's naturalistic but antipositivistic research programme was formulated in opposition to Hempel's neopositivism and Popper's hypotheticism. However, a critical analysis of both these standpoints contributed to an increased reception and popularisation of these views in the domains of philosophy and methodology of history. Because one needs to know what one is criticising or eventually critically develops, in Poland books by Hempel (Foundations of Science, 1968), Ernest Nagel (The Structure of Science, 1961, second edition 1970), and Karl Popper (Logic of Scientific Discovery, 1977) were translated and published..$^{12}$ However, this state of affairs delayed the reception of narrativism in Polish methodology in the humanities until the 1980s. Hayden White's 
Metahistory was unrecognised in Poland until the second half of the 1980s, with only a reference appearing in Topolski's Teoria wiedzy historycznej (Theory of historical knowledge) in 1983. ${ }^{13}$ One of the first articles devoted to White's work was by Jan Pomorski and appeared in 1986; ${ }^{14}$ whereas the first paper by White to be translated into Polish was published in 1989 in Pamiętnik Literacki.15

The reasons for this delayed reception of narrativism were manifold. Primarily the formal language and logical notions used by Poznan school authors hampered the reception of this standpoint. The ideas of the narrativists were mostly expressed through a language devoid of technical notions, which was more similar to belles-lettres discourse and common language with its ambiguities and lack of precision. ${ }^{16}$

Another barrier was the meta-methodological differences. A narrativism identified with antinaturalism does not undermine the adequacy of a positivistic model of explanation in the terrain of the natural sciences, but only questions its applicability to the humanities. According to White, historians "have more in common with their counterparts in literature than they have with those in the sciences ... History is no less a form of fiction than the novel is a form of historical representation."17 Meanwhile, the idealisational theory of science took up a stronger position, rejecting a positivistic model of explanation in the natural sciences as well in the humanities. Instead, it proposed its own universal model of science, applicable in all its domains and disciplines. Because of this, the antinaturalistic critique of the Hempelian model was unconvincing and uninspiring for the authors working within the Poznań paradigm.

Last but not least, political barriers should be mentioned. The antiscientism of narrativism undermined the meta-ideological position of Marxism. Its legitimisation was based on being a scientific ideology tout court. Although by the end of the 1980s Marxism was a dead ideology, people who held state positions due to Marxism were still active and they had considerable influence over scientific policy by being members of journal editorial boards and publishing house committees.

The full popularisation of narrativism was then only possible in Poland after 1989. At that time, under Ewa Domańska's editorship, Hayden White's collections of essays were published, as were Frank Ankersmit's. ${ }^{18}$ However, one could risk a thesis that the dissemination of narrativistic works, analogously as an acquaintance with neopositivistic works, did not give rise to critical reflection on narrativism - comparable to the response to neopositivism. For example, Topolski's book Jak się pisze i rozumie historie (How to write and understand history) is usually interpreted as a break with earlier phases of his intellectual development and not as a critique of the ideas of postmodernism in history. ${ }^{19}$ In Poland, the uncritical reception and imitation of narrativism can be more common than the critical incorporation of its concepts into theoretical frameworks by authors. There are many reasons for this state of affairs. One of them is the lack of analytical tools (or, properly speaking, the lack of acquaintance with them) caused by the fragmentation of the Poznan school and a certain impoverishment of its intellectual proposals. It is a pity because these are tools that would allow for a paraphrasing of the tenets of narrativism in the language of the school. ${ }^{20} \mathrm{Ac}-$ cording to a deformational concept of culture proposed by Nowak, idealisation is only one certain type out of the whole family of deformational procedures that can be divided into strong and weak forms. ${ }^{21}$ Examples of strong deformational procedures are reduction and transcendentalisation, 
while an example of weak deformational procedures is potentialisation (negative and positive). Let us assume that we have an initial object $O$, provided with a certain set of properties, which are characterised by a certain intensity. As a consequence of a transcendentalisation, object $O$ ' is provided with certain additional properties which the initial object does not have. The contrary one is a reduction, which relies on depriving object $O$ " of certain properties in comparison with the initial object. As a result of the use of positive potentialisation, the properties of object $O^{\prime}$ are characterised by a greater intensity than the properties of the antecedent object $O$. The procedure of negative potentialisation, instead, eventuates in an object, the properties of which are characterised by a lesser intensity than the intensities of the antecedent object's properties.

Constructs which are created in different realms of culture are a result of using complex deformational procedures. The idealisation used in science is a combination of reduction and negative potentialisation whereas fictionalisation, which is used in literature, is a combination of reduction and positive potentialisation. It allows for the question of whether history is closer to science or literature to be paraphrased in the following way: which deformational procedures find primary application in history - idealisation or fictionalisation?

Therefore, there is no gulf between science and literature or art because these domains of the human spirit use different deformational procedures requiring imagination and courageous thinking. This thesis puts another light on the narrativist critique of realism and objectivism in history, allowing for the limits of this standpoint to be highlighted.

\section{IV}

The main message of Chris Lorenz's Przekraczanie granic is the belief in the philosophical significance of historical research, which historians and philosophers do not always realise. In contrast, the knowledge of philosophical tradition affects the research practice of historians and their methodological consciousness. However, as Lorenz recognises, a philosophical reflection on history should not be detached from the research behaviour of the historian. The point of departure of all philosophical reflection on this matter should be a consideration of what historians really do. The point of arrival, such an interpretation of historiographical activity, allows for a deepening of our knowledge about the historian's craft. This message shapes the structure of the book. In the first part, Lorenz approaches the standpoint of Putnam's internal realism, which can be seen as a third way in current philosophical reflections on history. It opposes, on the one hand, objectivistic (positivistic) standpoints, and, on the other, relativistic (postmodernism, radical versions of narrativism) standpoints. The author's own presupposed analytical categories are applied in the second part of his book, where he analyses practices and discussions in historiography primarily in the German context.

In the chapter "Wiedza historyczna a prawa: rozdwojona historia" (Historical knowledge and laws: the dual history), Lorenz considers the problem of scientific laws in history. A significant dualism is revealed in this respect because, from the beginnings of history as a university discipline in the first half of the nineteenth century, two main orientations emerged: the first, the antinaturalistic approach, questioned the applicability of scientific laws in history; the second, the naturalistic ap- 
proach, postulated using the same methods from the natural sciences in the humanities. The author does not recognise that, in regards to this dispute, it is possible to apply the category of intellectual conversion. Adherents of contradictory positions tacitly assumed a common, namely positivistic, understanding of scientific laws. Lorenz indeed notes that in the second half of the twentieth century the positivistic standpoint was undermined by the post-positivistic picture of scientific laws in science. In this context, he mentioned Nancy Cartwright's influential book How the Laws of Physics Lie? ?2 However, according to Lorenz, the post-positivistic approach to science did not exert an impact on the theoretical historical debate in the methodology of history. ${ }^{23}$

\section{$\boldsymbol{V}$}

However, it is worth analysing the issue of the applicability of scientific laws in the research practice of historians from a perspective of a post-positivistic understanding of science introduced by the Poznań school. Let us now turn to the main concepts of the idealisational theory of science.

Idealisation: It is assumed that a number of factors influence the phenomenon under investigation. These can be divided into main and secondary factors. It is assumed by virtue of the idealising assumption $p(x)=0$ that when the factor $p$ equals zero it does not influence the phenomenon. Then one determines the way the phenomenon $(F)$ depends on its main factor $H$. An idealisation statement takes the form of a conditional clause: in its antecedent there are counterfactual assumptions according to which no secondary factors exert any influence on the phenomenon under investigation. And in succession to this conditional clause, the way in which the phenomenon under investigation depends on its main factor $H$ is shown. Graphically it is presented in the following way:

\section{(1) $U(x) \& p_{k}(x)=0 \ldots \& p_{1}(x)=0 \rightarrow F(x)=f_{k}(H(x))$}

Concretisation: The procedure consists in the gradual lifting of previously made idealising assumptions and introducing appropriate corrections to the initial formula of a statement. Through this procedure, one can see the way in which the phenomenon under investigation depends on secondary factors. Concretisation is complete when the factual statement in which there are no idealising assumptions is formulated.

$$
U(x) \& p_{k}(x) \neq 0 \ldots \& p_{1}(x) \neq 0 \rightarrow F(x)=f_{1}\left(H(x), p_{k}(x) p_{1}(x)\right)
$$

Approximation: In the research practice, final concretisation is never performed. The approximation of idealisational law relies on a waiving of all idealising assumptions and attributing a certain value to remaining secondary factors. This value $a_{1}$ is different from a minimal value of the secondary factor that is allocated to it in idealising assumptions and from the actual values adopted by it. However, this value should not exceed a certain threshold of accuracy $\varepsilon$ accepted in a given science at a given time. 
Explanation: An explanation of a given phenomenon consists of showing the dependence of the object under investigation on what is seen as the main factor for it. Then, from an idealisation law formulated in such a way, one derives increasingly realistic concretisations, which result in a formulation of a factual statement. The sentence being explained results from a factual (or approximative) statement and from its antecedent conditions, formulated on the basis of the procedure of concretisation.

\section{(4) $T^{k} \dashv T^{k-1} \dashv T^{0}($ or $\dashv A S)$ and $P \rightarrow E$}

Where - is the relation of concretisation; $\uparrow$ the relation of approximation; $P$ the antecedent conditions; $\rightarrow$ the relation of derivation; $E$ the statement to be explained; $T^{k}, T^{k-1}, T^{0}$ the sequence of idealisations statements; the upper index points the number of idealising assumptions; $T^{0}$ the factual statement; and $A S$ the approximation statement.

Such an understanding of scientific laws introduced new perspectives to the "theoretical historical debate", as Lorenz describes. As he says, this way of understanding the status of scientific laws has not received serious reception, yet it is worth presenting the assumptions of an idealisational understanding of science and their application in historiography. I would like here to juxtapose a Hempelian-Popperian scheme of explanation with an idealisational scheme. In the HempelianPopperian tradition:

- laws are inductive generalisations of historical facts or a set of factual hypothesis yielding a complex mechanism of historical development, and

- from such understood laws and antecedent conditions, the explanation of particular historical facts is derived.

The scheme of deductive-nomological explanation can be presented in the following way:

\section{(5) $L$ and $P \rightarrow E$}

Where $L$ is general law; $P$, the antecedent conditions; $E$, the statement describing the empirical phenomenon to be explained; and $\rightarrow$, the relation of derivation.

According to Hempel, a deductive-nomological model of explanation can be applied directly to reality. Any discrepancies between the value of empirical data and the result, derived from the model of explanation, lead to its rejection. However, as Hempel recognises, in scientific practice historians recall an explanation sketch which consists of an indication of the scientific law and antecedent conditions that are considered relevant to a given phenomenon. An explanation sketch requires further "filling out" to be transformed into a "full-blooded" explanation. The explanation sketch suggests only the direction that such a filling out should take. ${ }^{24}$

In the idealisational approach, the explanation should present dependency (in the form of a conditional statement) between the phenomenon $F$ and principle for it, factor $H$. Such a formulated ide- 
alisational law is concretised; this procedure relies on a gradual waving of idealising assumptions made previously and presenting the modified dependencies between the investigated phenomenon and principal, as well as secondary, factors. Concretisation ends with cancelling all idealising assumptions and drawing up a factual statement. The statement to be explained is derived from the factual statement and antecedent conditions.

This scheme of explanation may be illustrated in the following way:

$$
T^{k} \dashv T^{k-1}, \dashv \ldots \dashv T^{1}, \dashv T^{0} \text { and } P \rightarrow E
$$

Where -1 is the relation of concretisation; $P$, the antecedent conditions; $\rightarrow$, the relation of derivation; $E$, the statement to be explained; $T^{k}, T^{k-1}, \ldots, T^{l}, T^{0}$, the sequence of idealisations statements; the upper index points the number of idealising assumptions; and $T^{0}$, the factual statement.

In the idealisational theory of science, it is assumed that a scientist knows the mode of influence of each secondary factor on the investigated phenomenon..$^{25}$ When we reject this assumption, it appears that a scientist does not know how all the factors influence the investigated phenomenon. In this situation, the scientist concretises the idealisational statement by showing the impact of these secondary factors, which $\mathrm{s} /$ he knows how they influence the investigated phenomenon, and establishes through approximation the influence of the remaining secondary factors, which s/he does not know how they influence the investigated phenomenon.

The approximation of idealisational law relies on a waiving of all idealising assumptions at once and attributing certain values to remaining secondary factors. These values are different from the minimal values of the secondary factors that are allocated to them in idealising assumptions and from the actual values adopted by them. An approximation statement is accepted when the level of discrepancies between empirical data and the result derived from theoretical formula does not exceed what is generally accepted (defined more or less intuitively by the threshold of approximation) in a given domain of science at a given time. The use of approximation in a procedure of explanation means that "not the given F-fact but a class of $F$-facts, defined by the threshold of approximation, can be derived from such a structure" ${ }^{26}$ This scheme of explanation may be illustrated in the following way:

$$
T^{k} \dashv T^{k-1}, \dashv \ldots \dashv T^{l}, \dashv A S \text { and } P \rightarrow E
$$

Where $-\uparrow$ is the relation of concretisation; $-\|$ the relation of approximation; $P$, the antecedent conditions; $\rightarrow$, the relation of derivation; $E$, the statement to be explained; $T^{k}, T^{k-1}, \ldots, T^{l}$, the sequence of idealisational statements; the upper index points the number of idealising assumptions; and $A S$, the approximation statement.

\section{VI}

Let us consider now whether the explanatory sketch, proposed by Hempel, can be paraphrased using the notion apparatus of the idealisational theory of science. Let us remember that the scien- 
tist divides secondary factors into two groups. Belonging to the first group are those factors that $\mathrm{s} /$ he is able to enlist and knows their mode of influence on the investigated phenomenon. In the second group are those factors that $\mathrm{s} /$ he is able to enlist but does not know how they influence the investigated phenomenon. Therefore, the idealisational statement is concretised in regards to an influence of factors belonging to the first group. Approximation of the idealisational statement proceeds in regards to the influence of the factors from the second group.

However this is not always true in scientific practice. One can accept a more realistic assumption and, according to this, our scientist also approximates the idealisational statement in regards to the impact of enlisted factors $s /$ he knows influence the investigated phenomenon, but for different reasons (time, research purpose, own abilities etc) $\mathrm{s} /$ he is not able to concretise an idealisational statement. Therefore, our scientist divides secondary factors into three groups, namely those that:

(i) concretise an idealisational statement with regards to the impact of only some secondary factors, where s/he knows how they influence the investigated phenomenon;

(ii) approximate an idealisational statement with regards to the influence of the secondary factors, where s/he does not know how they influence the investigated phenomenon;

(iii) approximate an idealisational statement with regards to the influence of the remaining secondary factors, although $\mathrm{s} / \mathrm{he}$ knows how they influence the investigated phenomenon.

In this way, Hempel's explanatory sketch may be paraphrased in the notion apparatus of the idealisational theory of science. The "filling out" of the explanatory sketch relies on the continuation of concretisation in regards to the impact of secondary factors belonging to the third group. From the explanatory sketch, a wider class of facts than in the case of standard approximation can be derived. However, this is done at the expense of the accuracy of the explanation.

This idealisational status of scientific laws is maybe one of the reasons for their rare application in the research practice of historians. It is so because:

- the basic subject of the historian's research interest is, firstly, the reconstruction of historical facts or certain part of past reality and secondly, their explanation;

- the idealisational model of explanation cannot be directly applied to reality besides in classical cases where the influence of secondary factors is suspended;

- if historians resort to any theory (or scientific law), they are interested in the explanation of particular and usually unique historical facts, whereas the idealisational model of explanation allows the explanation of facts belonging to a given class;

- the application of a given idealisational law to the explanation of particular historical facts requires the building (by a process of concretisation and approximation) of a whole chain of idealisational statements, which usually goes beyond the competencies and, more importantly, 
the interests of historians who - due to the division of scientific work - are consumers rather than producers of scientific laws.

Recalling an example given by Lorenz, the historian is not interested in an explanation of why bottles filled with water cracked during subzero temperatures at night but why one of the bottles was cracked on the bottom and another one on the neck.

\section{NOTES}

1 Carl G. Hempel, "The function of general laws in history", reprinted in Carl G. Hempel, Aspects of Scientific Explanation and Other Essays in the Philosophy of Science, New York: Free Press, [1942] 1965, 231 and 239.

2 Hempel, "Studies in the logic of explanation", reprinted in Hempel, Aspects of Scientific Explanation, 249.

3 Hempel, “The function of general laws", 234.

4 For further details and literature on this issue, see Krzysztof Brzechczyn, "Logical empiricism and logical positivism", in Aviezer Tucker (ed.), A Companion to the Philosophy of History and Historiography, Malden: Blackwell, 2009, 416-426.

5 Western textbooks on the history of historiography (and on the history of analytical philosophy/methodology of history) after the second world war are written from a western (and/or Anglo-American) perspective and usually ignore what happened in these domains of the humanities and social sciences in Eastern Europe. An example is the paper authored by Chris Lorenz where the name of Jerzy Topolski is not mentioned at all (Lorenz, "History and theory", in Daniel Woolf and Axel Schneider (eds), The Oxford History of Historical Writing, vol. 5, Oxford: Oxford University Press, 2011, 13-35. Therefore, this paper can be seen as a modest contribution to incorporating the eastern European history of methodology and theory of historiography to a general history of these domains of science. Similar attempts in the domain of Sovietology was made by Krzysztof Brzechczyn in "Polish discussions on the nature of communism and mechanisms of its collapse: a review article", East European Politics and Societies 22 (2008): 828-855.

6 The most important achievements of Jerzy Kmita, which are not employed in this paper, were a humanistic interpretation and socio-regulative conception of culture. See Kmita, Essays on the Theory of Scientific Cognition, Warsaw/Dordrecht: PWN/Reidel, [1976] 1991; Kmita, Problems in Historical Epistemology, Warsaw/Dordrecht: PWN/Reidel, [1980] 1988. The intellectual output of Poznań school authors was presented in volumes of the Poznan Studies in the Philosophy of the Sciences and the Humanities, a philosophical book series founded by Leszek Nowak and published by Rodopi of Amsterdam; see also Anna Zeidler-Janiszewska (ed.), Epistemology and History (Poznań Studies in the Philosophy of the Sciences and the Humanities, vol. 47), Amsterdam/New York: Rodopi, 1996; Jerzy Brzeziński, Andrzej Klawiter, Theo AF Kuipers, Krzysztof Łastowski, Katarzyna Paprzycka, Piotr Przybysz (eds), The Courage of Doing Philosophy: Essays Dedicated to Leszek Nowak, Amsterdam/New York: Rodopi, 2007; Francesco Coniglione, Roberto Poli (eds), La realtà modellata: L'approccio idealizzazionale e le sue applicazioni nelle scienze umane, Milan: FrancoAngeli, 2008; Giacomo Borbone (ed.), Scienza, marxismo e metafisica: Leszek Nowak e la Scuola Metodologica di Poznań, Villasanta: Limina Mentis Editore, 2012.

7 I slightly modified the characterisation of the Poznań school authored by Krzysztof Brzechczyn and Piotr Przybysz in Andrzej Maryniarczyk (ed.), "Poznańska szkoła metodologiczna”, in Encyklopedia Filozofii Polskiej, vol. 2, Lublin: Polskie Towarzystwo Tomasza z Akwinu, 2011, 410-413, and Francesco Coniglione, Realtà e astrazione: Scuola polacca ed epistemologia post-positivista, Rome: Bonanno, 2010. 
8 Leszek Nowak, The Structure of Idealization: Towards a Systematic Interpretation of Marxian Idea of Science, Reidel: Dordrecht, 1980; Leszek Nowak and Izabella Nowakowa, Idealization X: The Richness of Idealization (Poznań Studies in the Philosophy of the Sciences and the Humanities, vol. 69), Amsterdam/New York: Rodopi, 2000.

9 Jerzy Topolski's best-known book, translated into many languages, was Methodology of History, Dordrecht: Reidel, 1976. A collection of Topolski's papers are contained in Krzysztof Brzechczyn (ed.), Idealization XIII: Modeling in History (Poznań Studies in the Philosophy of the Sciences and the Humanities, vol. 97), Amsterdam: Rodopi 2009.

10 Jerzy Topolski, “Toward an integrated model of historical explanation”, History and Theory 30 (1991): 324-338.

11 Jerzy Topolski, "Historical narrative: towards a coherent structure", History and Theory 26 (1987): 81.

12 Hempel, Podstawy nauk przyrodniczych [Foundations of Science], trans. Barbara Stanosz, Warsaw: Wydawnictwo Naukowo-Techniczne, 1968; Ernest Nagel, Struktura nauki: Zagadnienia logiki wyjaśnień naukowych [The Structure of Science], trans. Jerzy Giedymin, Bożydar Rassalski, Helena Eilstein, Warsaw: PWN, 1961; Karl R. Popper, Logika odkrycia naukowego [The Logic of Scientific Discovery], trans Urszula Niklas, Warsaw: PWN, 1977.

13 Topolski, Teoria wiedzy historycznej [Theory of historical knowledge], Poznań: Wydawnictwo Poznańskie, 1983,134 ; in a footnote, instead of its title, Metahistory appeared as its subtitle; whereas in the whole book, the name of Hayden White was mentioned four times.

14 Jan Pomorski, "Hayden White: historyzm jako relatywizm językowy w historiografii" [Hayden White: historicism as linguistic relativism in historiography], Annales Universitates Mariae Curie-Sklodowska 11 (1986): 189-202. Before 1989, a review of Tropics of Discourse was published: Sławomir Magala, "Review of Tropics of Discourse", Przeglqd Literatury Metodologicznej 5 (1988): 39-40.

15 Hayden White, "Zagadnienie przemiany w historii literatury" [The Problem of Change in Literary History], Pamiętnik Literacki 1 (1989): 277-293; it is also worth mentioning the translation into Polish of his "Problem narracji we wspótczesnej teorii historii" TThe Question of Narrative in Contemporary Historical Theory], in Jan Pomorski (ed.), Metodologiczne problemy narracji historycznej, Lublin: Wyd. UMCS, 1990.

16 Jan Pomorski, “Wprowadzenie: spory wokół narracji historycznej” [Preface: Controversies around historical narrative], in idem (ed.), Metodologiczne problemy narracji historycznej, Lublin: Wyd. UMCS $1990,13-14$ and 24.

17 Hayden White, Tropics of Discourse: Essays in Cultural Criticism, Baltimore/London: Johns Hopkins University Press, 1978, p. 82 and 122.

18 Frank Ankersmit, Narracja, reprezentacja, doświadczenie: Studia z teorii historiografii, ed. Ewa Domańska, Kraków: Universitas, 2004; Hayden White, Proza historyczna, ed. Ewa Domańska, Kraków: Universitas, 2009; White, Poetyka pisarstwa historycznego, eds Ewa Domańska and Marek Wilczyński, Kraków: Universitas, 2000.

19 Jerzy Topolski, Jak się pisze i rozumie historię: Tajemnice narracji historycznej [How to write and understand history: secrets of historical narrative], Warsaw: Rytm, 1996. For interpretations of Topolski's second phase of scientific development, see Jan Pomorski, "Jak uprawiać metodologię historii? Wokót koncepcji Jerzego Topolskiego" [How to do methodology of history: among the concepts of Jerzy Topolski], in idem (ed.), Światooglqdy historiograficzne, Lublin: Wyd. UMCS, 2002, 19-20; Szymon Malczewski, 'Metodologie' Jerzego Topolskiego" [“Methodologies” of Jerzy Topolski], Historyka: Studia Metodologiczne 39 (2009): 89-120. 
20 For some attempts, see Krzysztof Brzechczyn, "Between science and literature: the debate on the status of history", in idem (ed.), Idealization XIII: Modeling in History (Poznań Studies in the Philosophy of the Sciences and the Humanities, vol. 97), Amsterdam/New York: Rodopi 2009.

21 Leszek Nowak, "Thoughts are facts of possible worlds: truths are facts of a given world", Dialectica 45 (1991): 273-287; Nowak, "On the hidden unity of social and natural sciences", in Krzysztof Brzechczyn and Katarzyna Paprzycka (eds), Thinking about Provincialism in Thinking (Poznań Studies in the Philosophy of the Sciences and the Humanities, vol. 100), Amsterdam/New York: Rodopi, 2012, 30-35.

22 Nancy Cartwright, How the Laws of Physics Lie?, Oxford: Oxford University Press, 1983.

23 Chris Lorenz, "Geschichtswissenschaft und Gesetze: eine zwiespältige Geschichte”, in Wolfgang Bock (ed.), Gesetz und Gesetzlichkeit in den Wissenschaften, Darmstadt: Wissenschaftliche Buchgesellschaft, 2006, 87 (page refers to Polish translation).

24 Hempel, "The function of general laws in history", 238.

25 Leszek Nowak, Wstęp do idealizacyjnej teorii nauki [Introduction to the idealisational theory of science], Warsaw: PWN, 1977, 134.

26 Leszek Nowak, "The idealizational approach to science: a new survey", in Nowak and Nowakowa, Idealization X, 129. 